\title{
Difference of def-t and DMF-T Index of Autism Children and Normal Children
}

\author{
Yetty Herdiyati Nonong ${ }^{1}$, Eka Chemiawan ${ }^{2}$, Prima Abigail Gayatri ${ }^{3}$ \\ 1,2,3 Faculty of Dentistry, Universitas Padjadjaran, Bandung, West Java, Indonesia
}

\begin{abstract}
One of the problems in the development of a child is autism. Children with autism have limitations in social interaction and communication. There are differences in parenting and food consumption between normal and autistic children that may lead to differences in caries activity. The research was conducted in order to obtain the difference of index def-t and DMF-T between children with autism and normal children. This study was performed as a cross-sectional analytical research, using equality of two proportions and Mann-Whitney to analyze the differences of index def-t and DMF-T index children with autism and normal children. The research sample consisted of 23 children with autism of Yayasan Our Dream, Yayasan Pelita Hafizh and SLB Prananda and 23 normal children of MI Cikapayang. The results of this research showed that the index def-t of children with autism was 1.21 and normal children was 3.69. The DMF-T index of children with autism was 1.56, while the normal children were 2.26. The conclusion of this research was that there was no significant difference in def-t index in children with autism and normal children except for the " $e$ " (indicated for extraction) and there was a significant difference in DMF-T index between children with autism and normal children.
\end{abstract}

Keyword: def-t index, DMF-T index, autism children, normal children

\section{Introduction}

Children with autism have problems in interacting with the social environment and communicate, so that children with autism need special attention (special care) about the maintenance of healthy teeth and mouth from an early age by parents ${ }^{[1]}$. Parents have a major influence on a child's health. Maintenance of oral health of children becomes a factor to be considered a parent early on, especially in children with autism.

Motor and communication inability in children with autism lead to a perception that children with autism have dental and oral health is poor compared to normal children. The autistic behavior makes routine maintenance and control of dental and oral hygiene becomes very difficult. Children with autism tend to have power and masticatory muscles are weak and less able to coordinate so easily salivate. They prefer sweet foods and less able to coordinate tongue and masticatory muscles, causing them prefer to keep food in the mouth than chewed. The habit of eating sweet foods and their behavior is exactly what is causing the autistic individuals susceptible to caries ${ }^{[2]}$.

A study in Turkey and Surabaya refute the statement. The study proves that children with autism have better caries prevalence compared with normal children at an early age because of controlling the consumption of foods containing sugar. Dietary adjustments in autistic children have been done early and maintenance actions performed oral health and directly supervised by a caregiver or parent ${ }^{[1]}$. In contrast to normal children, parents often do not pay attention to that child normal food consumption is seen more frequently cariogenic foods and lack of control healthy teeth and good oral are some things that can trigger the appearance of caries in normal children.

The purpose of the study is to collect data and see the difference in index of def-t and DMF-T between children with autism with normal children in some educational institutions, among others, Our Dream Foundation, Yayasan Pelita Hafiz, SLB Prananda, and MI Cikapayang Bandung.

\section{Material and Method}

This research is an analytic comparative with crossover study Cross-sectional design, as well as aids, stationery and questionnaires. Samples were 23 autistic children and 23 normal children aged 7-12 years were determined using purposive random sampling technique.

The variables in this study consisted of caries, autistic children and normal children. Tools and materials required in the examination, among others, the glass mouth, explorer, tweezers, alcohol $70 \%$, cotton, water, cotton pellets, sheets charging researches and questionnaires. Questionnaires were given to normal children and parents of autistic children to look at the factors that influence the setting of dental caries differences between autistic children and normal children. Caries examination that was performed using the formula def-t (decay, indicated resources for extraction, filled, teeth) for primary teeth and DMF-T (Decay, Missing, Filled, Teeth) for the permanent tooth. The formula used to calculate caries namely:

$$
\text { def-t index }=\frac{\text { def-t number of teeth }}{\text { the number of children assessed }}
$$

DMF-T number of teeth

$$
\text { DMF-T index }=\frac{\text { De number of children assessed }}{\text { the }}
$$

This research was conducted in two visits. On the first visit researchers noted the child's identity (name, sex, and age), giving informed consent, as well as a questionnaire for normal children and a questionnaire for parents of autistic children. In the second stage of inspection visits dental caries 


\section{International Journal of Science and Research (IJSR) \\ ISSN (Online): 2319-7064}

Index Copernicus Value (2013): 6.14 | Impact Factor (2015): 6.391

using the formula above and then recorded on the inspection sheet provided.

\section{Result and Discussion}

Samples were obtained as many as 56 children, consisting of 23 autistic children and 23 normal children

Table 1: School Studied Based Children Frequency Distribution

\begin{tabular}{|c|c|c|c|}
\hline No. & School Name & f & $\%$ \\
\hline 1. & Yayasan Our Dream & 10 & 21.73 \\
2. & Yayasan Pelita Hafizh & 7 & 15.21 \\
3. & SLB Prananda & 6 & 13.04 \\
4. & MI Cikapayang & 23 & 50 \\
\hline \multicolumn{2}{|r|}{ Total } & 46 & 100 \\
\hline
\end{tabular}

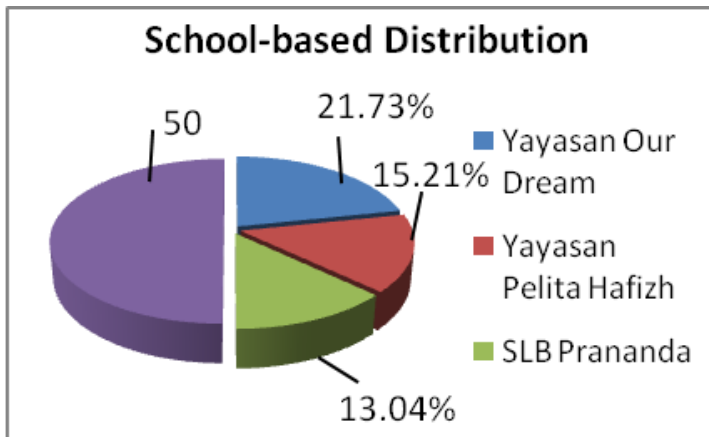

Figure 1: School-based Distribution

According to the table and diagram above, the majority of school respondents were MI Cikapayang is 23 people (50\%), then the Foundation Our Dream is 10 people $(21.73 \%)$, Yayasan Pelita Hafiz of 7 people (13:04\%), and the rest SLB Prananda is 6 people $(13: 04 \%)$.

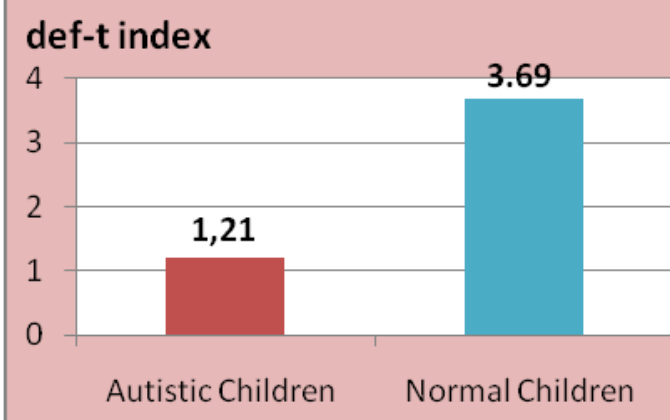

Figure 2: Comparison of def-T index of Autistic Children and Normal Children

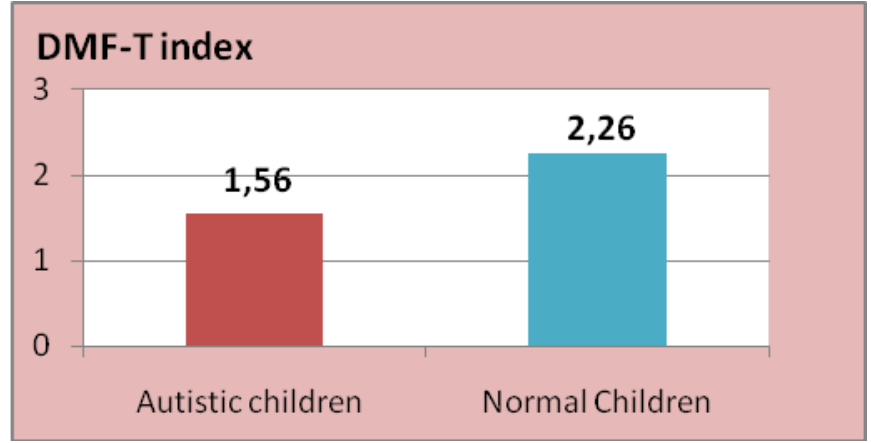

Figure 3: Comparison of DMF-T index of Autistic Children and Normal Children
Descriptive research results show that the index DMF-t in normal children is higher than children with autism. Statistical testing with Mann-Whitney test was conducted to determine whether there were significant differences between index-def $\mathrm{t}$ autistic children (Our Dream Foundation, Pelita Hafiz and Prananda SLB) and normal children (MI Cikapayang) in our Bandung. The results showed no significant difference in the index def-t between autistic children and normal children except for the index "e" that show the differences were very significant at $\mathrm{P}=0.002$. In the DMF-T values showed significant difference in the index DMF-T between autistic children and normal children, namely $\mathrm{P}=0.039$.

Different value in the index can be caused by several factors, such as the role of parents in raising and maintaining oral health is different between autistic children and normal children, differences in diet and oral health maintenance. In general, the oral health of children with autism have a lesser degree than in normal children. Children with autism have a high level of caries risk because of their inability to understand and use verbal language as a medium of communication so that they are not able to capture and understand the information provided by the environment ${ }^{[3]}$. Increased risk of caries is supported by the ability of the muscles of mastication they are very less and their fascination with sweet foods, causing an increased risk of dental caries in children with autism ${ }^{[4]}$.

DMF-T index value in normal children showed larger values of children with autism by 2.26 to 1.56 for normal children and children with autism. This is consistent with the results of a survey conducted by researchers that the large role of caregivers in autistic children in maintaining their oral health. By 17 of the 23 respondents who have children with autism studied assist in maintaining their oral health by going directly to brush their child's teeth.

$43 \%$ of respondents who have children with autism do special carbohydrate diet to avoid excessive hyperactive behavior in children with autism. Gluten and casein are carbohydrates that should be avoided by children with autism. This is because these two types of carbohydrates have proteins that are difficult to digest. Digestive enzymes in children with autism is very less, so as to make food is not digested by semupurna and cause indigestion. Moreover, it can lead to complaints of diarrhea and can affect the central nervous system, causing an autistic child appear hyperactive [5]. Minimum consumption of carbohydrates is exactly what causes dental caries in children with autism lower. Organic acids are formed as a result of fermentation of a carbohydrate metabolism in plaque causes the $\mathrm{pH}$ falls below normal and there demineralization of dental caries ${ }^{[6]}$. In children with autism, demineralization process is running a minimum because of the limited consumption of carbohydrates, causing a decrease in the risk of dental caries.

A significant difference in the value of " $\mathrm{e}$ " (the tooth with the indications of extraction) in t-def index higher-def is shown in the index $t$ normal children. It is influenced consumption and frequency of consumption of sweet foods in normal children is often limited by their parents. In addition, as many 
as 14 or $60 \%$ of normal children more like sweet foods. This situation if not accompanied by the maintenance of good dental resulted in an increase of dental caries for dental health maintenance are less effective as brushing your teeth while taking a bath alone can lead to the collection of plaques and cause dental caries. Besides the consumption of carbohydrates higher in normal children is also one factor of caries. Carbohydrates are the substrate of bacteria in plaque can produce acids and the synthesis of extracellular polysaccharides. Availability glucose metabolism of carbohydrates can encourage bacteria to produce lactic acid and cause demineralization of tooth enamel. One type of carbohydrate that is often found in food are sucrose and sucrose is the most carbohydrates play a role in the formation of caries compared to other types of carbohydrates ${ }^{[7]}$.

\section{References}

[1] Namal, Necmi. Hayrite Ertem Vehit, Selcuk Koksal. 2007. Do Autistic Children Have Higher Levels of Caries? A Cross-sectional Study in Turkish Children. J Indian Soc Pedod Prev Dent. 97-102.

[2] McDonald, Ralph E., David R. Avery and Jeffrey A. Dean. 2011. Dentistry for the Child and Adolescent $9^{\text {th }}$ ed. Missouri: Mosby Elsevier. 177, 185, 475.

[3] Marshall, Jennifer. Barbara Sheller and Lloyd Manci. 2010. Caries-risk Assessment and Caries Status of Children with Autism. Pediatric Dentistry Volume 32/1/no 1 Jan/Feb. 69-75.

[4] Bhalla, J. 2006. Autism and Dental Management. Ontario Dentist. 27-29.

[5] Suryana, A. 2004. Terapi Autisme, Anak Berbakat dan Anak Hiperaktif. Jakarta: Progres. 9-11, 15-18, 26-27, 43-47, 77.

[6] Robert H, et al., 2007. Dental Caries. 369, 9555; ProQuest Research Library pg. 51

[7] Cameron, Angus C and Richard P Widmer. 2003. Handbook of Pediatric Dentistry $3^{\text {rd }}$ ed. Australia: Mosby Elsavier. 39-43.

\section{Author Profile}

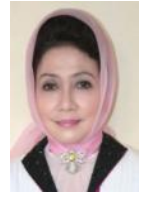

Yetty Herdiyati Nonong (Indonesia) received DDS from Universitas Padjadjaran in 1979. She continued to specialist program in Pedodontics in Universitas Padjadjaran and graduated in 1995. She finished her doctorate degree from Universitas Padjadjaran in 2007. She is a lecturer in Pedodontics Department of

Universitas Padjadjaran. She is also a member of Indonesian Dentist Association and Indonesian Pediatric Dentist Association.

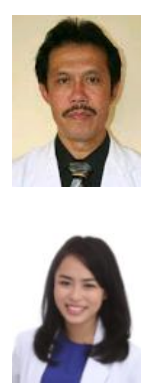

Eka Chemiawan (Indonesia) received DDS from Universitas Padjadjaran in 1986. He received Master of Health degree from Universitas Padjadjaran in 2000. $\mathrm{He}$ is a lecturer in Pedodontics Department of Universitas Padjadjaran.

Prima Abigail Gayatri (Indonesia) received BDS in 2012 and DDS from Universitas Padjadjaran in 2014. She is currently attending orthodontic residency program at Universitas Indonesia. 